\title{
China and its wests - evolution of security dynamics and its consequences for the defence industries of the involved actors
}

\author{
Magdalena Markiewicz ${ }^{1}$ \\ ${ }^{1}$ Royal United Services Institute for Defence and Security Studies - RUSI
}

\begin{abstract}
OBJECTIVES: The research objective of the paper is to analyse the recent, ever more pronounced shifts and changes in security dynamics between China and its "Wests".

METHODS: The methods used in the study consist of in-depth going qualitative research and analysis of Western journals as well as an investigation and translation of primary Chinese sources.

RESULTS: Each cooperation effort and security partnership between China and the analysed partners means that the defence capabilities of one player will affect those of the other. This is a matter of concern for those who are currently in a position that relies on the import of military and intelligence equipment from stronger actors, as such a relationship may provide easier access and leverage for giants such as China to influence their domestic foreign policy and security agendas.
\end{abstract}

CONCLUSIONS: The results of the study shed light on the on-going relevance of the question: is it possible to find space in which actors can achieve their own security objectives that is beneficial for the development of their defence industries without challenging the foreign policies of one another? Can competition between China and the actors it interacts with be conducted primarily in the political and economic field, with security relations only focusing on peaceful imports and exports instead of an arms race? One may only speculate.

Keywords: Defence Industry, Security, Strategy and Foreign Policy, China

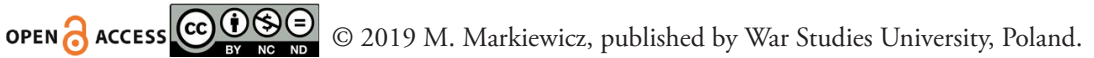
This work is licensed under the Creative Commons Attribution-NonCommercial-NoDerivatives 4.0 License. 


\section{Introduction. Chinese approach to security. Context. Current Capabilities. Future Pivot}

The security dynamics between China and "its Wests" - Russia, Iran, the European Union, NATO and Australia, have been undergoing shifts and changes of direction for decades. Over the past months, however, these swings have become considerably more pronounced. This has been the result of the recent political developments, amongst them the election of Donald Trump as the 45th US President and consequent instabilities in terms of the US foreign policy towards diverse international actors, China's ongoing build-up of trade and its ever-expanding geostrategic cooperation projects such as its Belt and Road Initiative and also of the inherent cultural, ideological and political differences between Beijing and its partners. Studying and analysing the dynamics between the players who interact regularly with Beijing has become necessary as China's growing influence on the domestic security and national foreign policy agenda schemes of the governments who cooperate with it, is often a matter of concern for them.

The roots of the recent security-related shifts in dynamics between China and its "Wests" and the consequences of these fluctuations, are likely to affect national defence industries of the concerned countries in a significant manner. If these changes are not analysed as they are evolving at present, but instead are only tackled once the consequences for defence industries reveal themselves, one will not be able to mitigate their potential negative outcomes and the resulting challenges to the national security of those involved.

The research objective of the paper is to examine the reasons for the recent evolution of China's security engagement efforts with its Western partners: Russia, Iran and the liberal democratic West - here represented by the European Union and NATO as examples of Western multilateral organisations, and Australia - an illustration of a conventional democratic nation-state society, based on the bilateral modus operandi.

If these changes are not analysed as they are evolving at present, but instead are only tackled once the consequences on defence industries reveal themselves, one will not be able to mitigate their potential negative outcomes and the resulting challenges to the national security of the involved.

The choice of particular examples of China's Wests studied in this paper can be explained - in the case of Russia and Iran - by their cultural and economic importance. Grouping the EU, NATO and Australia within one liberal democratic West category is based on 
the idea that such compartmentalisation of actors who share common values should permit a wider conceptualisation of the general security dialogue patterns between China and the liberal democratic world. At the same time, this is not to suggest that the author ignores the differences between the democratic models, cultures, politics and social characteristics of the actors that fall within this category.

The starting point of the paper will concern itself with the description of the context in which Chinese security relations with its Western partners are nested; an analysis of the origins of the Chinese approach to international relations as such is the basis necessary to place contemporary Chinese foreign policy within a broader contextual background. Studying the past as well as the present historical, social, economic and political drivers influencing the Chinese stance on security allows Beijing's approach to it to be conceptualised as a multidimensional product of China's civilisational development, its present defence capabilities and challenges the country it is currently grappling with. The product of this past/present combination then permits us to better comprehend China's recent Western pivot, and the possible future consequences stemming from it.

In order to fully comprehend the dilemmas, challenges as well as the evolution of security dynamics between China and its multiple Wests, it is necessary to understand Chinese cultural, social, political and ideological realities as well as the pace at which China has been developing its defence capabilities historically.

The civilisational context and the drivers pushing and pulling the security relationship between China and its Western partners in diverse directions help justify the scope and nature of the development of the present defence partnerships. The past and the present are thus inherently interlinked with the likely future direction of the Chinese security relations with the partners that are studied in this paper - the Central Asian region, Russia, Iran and the liberal capitalist "West" - exemplified through the case studies of the EU, NATO and Australia.

\section{Past - Cultural Background}

The Chinese mindset, especially when considering cooperation with external stakeholders, is very much based on the cultural and ideological heritage of the Chinese civilisation (Hua 2018, p. 1). Consequently, when analysing Beijing's contemporary foreign policy, 
the cultural background behind the Party's decisions should not be ignored (American Historical Association 2018).

Following the establishment of the Communist People's Republic of China in 1949, up until Mao Ze Dong's death in 1976, the country actively rejected relations with most external actors. The Maoist period was characterised by the country's almost total rejection of free market principles and steering away from international institutions (Bray and Jeffreys 2016, pp.13-16). Such isolation made the distinction between China and the "West" much clearer in ideological, economic, social and cultural terms. The characteristics of a communist 'party-state' as well as the short- and long-term consequences of their implementation on various aspects of Chinese life, culture and social development have influenced an external perception of the country as a veritable revolutionary and one unwilling to interact with the liberal democracies of the West (Hua 2018, p.1). According to Henry Kissinger (2012, p. 100), Chinese leaders have never historically conceived their country's security to be based on international, legal mechanisms, which rely on values prioritising a community of sovereign states cooperating to assure mutual security and peace. Chinese leaders were, instead, trained on the basis of the notion of Shi - the ability to understand and strive within the matters in flux and chaos, unlike any legal international documents, which aim to institutionalise international rules of behaviour. China's formation of alliances stems, therefore, more from an awareness that such action would potentially lead to strategic advantages than from a willingness to achieve peace through international cooperation (Kissinger 2012, p. 80).

The situation started to change with the institution of Deng Xiao Ping's policies in 1979, intended to develop the Chinese economy and to open China to the outside world. The transformation witnessed the structural shift from the country's emphasis on embodying the principles of a 'nation-state' model to becoming a de facto 'party-state'. Ever since then, China has been on a continual, but somewhat bumpy path towards the development of increased interactions with external actors as a means to secure its position in the global arena (Wolf 2018). After its opening up to external interactions after the 1970s and increasingly so in the 1980s, the Chinese leadership's underlying purpose became to turn this independence from external partnership into a 'weapon' and a mechanism of cooperation based primarily on the awareness of shared perceptions. Still, however, reciprocal obligations between China and the allies it decided to partner 
with had its starting point in an assumption of the similarity of a common threat rather than common values or ideology (Kissinger 2012, p. 200).

\section{Developing Present Security and Defence Capabilities}

Beijing has been placing an increased emphasis on improving its military capabilities, in all three core domains (Gertz 2016). In the air, the fifth generation Chengdu J-20A is of particular note due to the fact that it aims to challenge the latest American designs in quality, rather than simply relying on quantity. The $\mathrm{J}-20 \mathrm{~A}$ models began service in the PLAAF squadron in 2017 (Gady 2018). Additionally, the Chinese PL-15 extended range air-to-air missile system will soon be equipped with active, electronically scanned array (AESA) radar technology - until recently the sole preserve of advanced Western and Japanese designs (Gertz 2016). Additionally, in terms of its naval capabilities, China has been developing its defence industry with growing speed (Hardy and Skomba 2014). China's programme over the last 15 years has emphasised the need to overtake Japan, India and South Korea combined in terms of the number of new corvettes, destroyers, frigates and submarines (Shepherd and Michael 2018). The number of new warships launched by Beijing in the last four years alone is greater than the entire French navy (Hardy and Skomba 2014). The launch of the PLAN's Type-055 cruiser is an example of China's ambition for its blue-water capabilities. With the Type-055, and other new equipment, PLAN is already able to deploy missiles further than ever before - including off the coast of Europe (Marcus 2018).

Beijing's military build-up has been accompanied by Chinese trade and infrastructure investments over its Western borders, such as the Belt and Road Initiative (BRI), which are crucial to fulfilling the country's domestic economic and security goals (Pantucci and Lain 2017). A key strategic interest is how the host countries perceive these projects, particularly as China's foreign policy is increasingly focused on its involvement in Central and South Asia (Shepherd and Michael 2018, Gertz 2016) 


\section{Belt and Road Initiative}

In relation to BRI, Beijing first decided to focus economic investments on its near peer partners - the countries of Central Asia. Traditionally, the region had been the route of the ancient Silk Road, serving as a veritable commercial channel connecting China with the Middle East, and further still, Europe. As a consequence, Central Asia is a strategically important actor that China has growingly been focusing its cooperation efforts on. Indeed, China's particular interest in its western border regions is largely connected to its domestic security policies as Beijing is concerned about national stability within its borders, especially in Xinjiang (its westernmost region currently dealing with tensions between the Han and Uighur national groups), and sees domestic economic prosperity as well as border stability as inextricably linked to the economic development and social well-being of neighbouring countries. From China's perspective, this prosperity is key to stabilising Xinjiang, and this idea has become one of the crucial drivers of further development of the whole BRI concept: the mutually beneficial project developing infrastructure, which will assure domestic economic wealth but also will secure the necessary conditions needed for social stability. Nonetheless, despite the Chinese emphasis on economics, the country's increased projects in the Central Asian region have raised concerns regarding China's growing involvement in regional security relations. Indeed, Beijing's increasing presence abroad in the form of economic initiatives will require China to take measures to assure protection of its assets from potential instabilities. What follows is that Chinese citizens, who already constitute the majority of the workers hired in the Chinese projects in Central Asia and the Middle East, will also need adequate protection in order for these interests and agendas to be maintained. China is wary of depending on the host countries' governments to provide the Chinese with the security they seek.

Moreover, the Central Asian host countries interacting with China may ask themselves whether Beijing, the traditional strong believer in the Westphalian principle of the non-interference, will now change its modus operandi and become more involved in the countries' domestic political affairs, which, in turn, may pose a challenge to the progress of the development of the BRI.

In reality, the ultimate aim for Beijing is to develop a series of trade and economic corridors using Chinese companies (to allow them to expand their reach across the borders) to guarantee the development as well as security domestically. As a result, 
though, Chinese involvement in Central Asian countries' domestic affairs will only go so far as it is in line with the protection of the Chinese interests. Chinese expansionist initiatives merely for the sake of it are highly unlikely to take place in this context.

Even though a matter of concern for some host countries, the advantages stemming from the implementation of the BRI and of the overall Chinese engagement in the Asian region as well as internationally, will not only encompass the economic development and financial perks; the increased connectivity and continual interaction between the players may be an efficient guarantee of stability in terms of security relations. Indeed, the Belt and Road Initiative reflects the Chinese move towards greater connection and tighter links between its diverse Wests.

\section{China and its immediate West - China/Russia security dynamics}

In terms of the security relationship between Russia and China, according to Dr. Gabuev, the chair of the Asia Pacific/Russia at the Carnegie Centre, the Crimea crisis and the resulting Western sanctions have caused a remarkable shift not only in terms of the dynamics between Russia and the liberal democratic Western societies but also with respect to the nature of relations between Russia and its Eastern partners (Gertz 2016). Gabuyev notes that, for centuries, China has been fixated on its relations with its nearest West, especially after the fall of the USSR. Before the disintegration of the Soviet bloc, China and the USSR had maintained close ties due to their ideological proximity, although these were often strained throughout the duration of the Cold War. After the collapse of the Soviet Union, China turned to actively seeking new partners in the Western societies deeming Russia as weak and unable to provide China with the type of economic advantages it needed to become a powerful international actor.

An asymmetrical relationship is thus forming; one where China profits from imports of advanced, cutting-edge military equipment from Russia and access to cheap gas and oil supplies, whilst Russia is becoming increasingly dependent on Chinese exports as access to its traditional partners is constricted (Bolt and Cross 2018).

It is difficult to establish whether Russia and China maintain close defence procurement links due to tangible strategic interests or rather a simple axis of convenience (Haenle and Gabuev 2018). Whilst the two are unlikely to take any steps to seriously threaten 
the relationship with one another, there exist several possible challenges that are worth taking note of (Legarda 2018).

Firstly, the Central Asian republics, which have traditionally been economically dependent on Russia, are now relying more on Chinese investments, most recently as a result of the BRI initiative (Pantucci and Lain 2017). Consequently, Beijing threatens the longstanding Russian financial advantages stemming from its traditional trading and geopolitical dominance within the region (Gertz 2016, Pantucci and Lain 2017). Another potential security factor is the Sino-Russian border (De Haas 2013). The Russian concern is that China could annex some parts of the country's Eastern border provinces which are scarcely populated by ethnic Russians, while bordering with the heavily industrialised Chinese Dong Bei province (Legarda 2018).

In reality, wages on the Russian Eastern borders are not much higher than those on the Chinese side; therefore, Chinese migrants who decide to improve their financial situation abroad tend to venture further West (De Haas 2013). Additionally, both actors are economically compatible - China has few natural resources whereas Russia has substantial reserves, they are therefore natural partners in trade (Pantucci and Lain 2017). China is also a strong proponent of national sovereignty as the main pillar of its foreign policy, which is one of the most important aspects of the Russian foreign policy as well (Bolt and Cross 2018).

Another security concern between China and Russia is the Xinjiang province (Western border province of China, populated by the Muslim Uighur minority, which has strong cultural, historical and ethnic links to the peoples of Central Asia and has been known to include some militant extremist groups). The alleged Uighur networks with ties to AlQaeda radiate across the Chinese border into Russia and constitute a source of worry for Russia and result in voices claiming that more border control and increased militarisation of the Sino-Russian frontiers are necessary. Some discontent has also been expressed by the Russian side which claims that the Chinese tackle the issue of Islamic extremism in an inefficient manner, which constitutes a grave threat to Russian domestic security. Nevertheless, Beijing and Moscow have been able to maintain relations, with both steering clear of raising the most contentious issues - human rights abuses, Chechnya, and security in Xinjiang (Bolt and Cross 2018).

Overall, China's modus operandi with regard to Russia bases itself upon neutrality and cherry-picking whatever fits with Chinese policies. Indeed, historically, when 
interacting with external actors, the Chinese leadership has been known not to take sides in ideologically fuelled disputes nor to emphasise normative values; rather it has been one to prioritise calculated pragmatism instead.

In the future, the longstanding Chinese practice of reverse engineering will hasten Chinese self-sufficiency in terms of production of cutting-edge military equipment (Haenle and Gabuev 2018). If the Chinese defence industry continues to develop as it is doing at the present rate, Chinese imports from Russia in the field will probably gradually dwindle (Chan 2016). For the moment, however, China continues to import high-value modern defence equipment from Russia - the Su-35 fighter aircraft and S-400 surface-to-air missile system, which will continue to provide financial profits for the Russian economy for the foreseeable future.

\section{China's security relationship with Iran. Beijing's impact on Iran's Defence Capabilities}

Nadimi (2016) argues that amid the changing dynamics and the shifting Iranian focus towards increased cooperation with China rather than continuing on the traditional path towards maintaining cooperation with Russia, Tehran and Beijing are entering a new era of strategic partnership, including the potential transfer of advanced weapon systems (Yao 2014). This growing security cooperation between the two has been said to have been the consequence of the zig-zagging Western attitudes, as well as the Iranian hard-liners' perception of the European Union as merely an extension of American foreign policy. The dynamics of this bilateral relationship will probably remain centred around counterbalancing the US (Gippner 2016, p. 111). China is already the key provider for the Iranian infrastructure with regard to its energy reserves (Gady 2016). To tighten existing links, Iran has been actively signalling its eagerness to join the Shanghai Cooperation Organisation, of which China is the de facto leader (Legarda 2017).

With the present, increased interconnectedness between Tehran and Beijing, Iran has been keen on acquiring Chinese Chengdu J-10B fourth-generation fighter jets as well as airborne radar and avionics components to improve its own future designs (Hindi 2017). The Iranian unmanned aerial vehicle (UAV) industry could also potentially benefit from the equipment provided by China, as Beijing has been developing an ever-wider range 
of drones. Furthermore, to secure further benefits for the Iranian defence industry, an Iranian electronic defence firm SaIran signed an agreement with Chinese firms in 2015 to start using their BeiDou-2 satellite navigation system for military purposes (Nadimi 2016). Additionally, Iran is likely to attempt to obtain modern Chinese battle tank designs, among them the MBT 2000 or the MBT 3000 (VT-4), as well as armoured personnel carriers.

In terms of the naval defence industry, Iran wants to secure cooperation with China, especially with regard to acquiring supersonic missiles such as CM-302, the CX-1, or the YJ-22. If imported from China, these weapons would increase Iranian ability to deny external actors' freedom of action in the Persian Gulf (Nadimi 2016)

The more China and Iran cooperate, the more scope there is for disagreement. However, because both actors are aware of some potential sources of friction, they are investing additional efforts to maintain a positive relationship in other fields, for instance the development of anti-ISIS efforts in Afghanistan. They also avoid most contentious topics (even though Iranians often call for respectingthe human rights of oppressed Muslims around the world, they never specifically refer to the Chinese Uighur minority) (Nadimi 2016).

\section{Chinese security relations with the liberal democratic West}

\section{The European Union}

In terms of its military capabilities, the EU has generally been seen by Beijing as a soft power with minimal defence capacity (Cowie 2015). It has, nonetheless, recently become a strategic actor in the tense relationship between China and the US (Ratner 2018). Indeed, China has been putting pressure on the EU to issue joint statements against Trump's trade policies. During meetings in Brussels, Berlin and Beijing in recent months, senior Chinese officials, including Vice Premier Liu He and the State Councillor Wang Yi, have agreed to open more of the Chinese market to the European partnerships (Pacheco Pardo 2017).

In terms of security dynamics and its consequences for defence capabilities, Beijing aims at building support among countries like the EU member states on specific issues, 
such as recognition of territorial claims in the South China Sea (Kissinger 2012). Also, China recognises that mutual efforts with international institutions in areas of counterterrorism are necessary to secure domestic stability (Maher 2017, p.134). Consequently, efforts such as anti-piracy operations in the Gulf of Aden are taking place. Beijing is also acutely aware that Europe has many assets such as the technology and cyber security industry, which China needs for its continued industrial development (Kissinger 2012, p. 327). China senses that a window of opportunity to pursue such goals has opened recently with the Trump administration's apparent withdrawal from the role of guardian of multilateralism.

As for the European Union take on defence and security relations with China, European exporters continue to seek new export opportunities, despite the lack of any coherent EU approach in terms of arms sales and controls on the transfer of critical technologies (Pacheco Pardo 2017, NATO 2018). This situation could, nonetheless, change soon if the Chinese trade relationship with the United States continues to deteriorate (Duchatel 2018, Cowie 2015). European arms exports to China have already shown signs of better performance in areas that are not dominated by the US, such as diesel submarines and some niche naval systems. (Duchatel 2018).

\section{NATO}

China has never held a strong belief in alliances and global institutions as an indispensable element of the world order. China rejects the notion that the transatlantic alliance, especially NATO, or any alliance for that matter, can legitimise the use of force for military intervention (Pacheco Pardo 2017, pp. 301-203).

Beijing has had a very bumpy relationship with the North Atlantic Treaty Alliance since the 1999 Kosovo War in which NATO forces bombed the Chinese embassy in Serbia. Indeed, as China kept rejecting the notion of the primacy of international alliances in general, it saw little reason to engage with NATO as other non-member states usually have it in their custom - by having its representative present at the NATO headquarters in Brussels and participating in strategic bilateral meetings (Duchatel 2018).

That said, over the past few decades. China's perception of NATO has been gradually evolving. Indeed, the ongoing threat of Islamic radicalism and NATO's role in 
Afghanistan have both had a significant impact on the Chinese strategic thinking. As a result, China had its first ever meeting with NATO officials in Brussels in 2002, with the first visit of a NATO official to China in 2009. The development of China's relations with NATO has not ended there -2012 marked the first appointment of a high-level Chinese representative to NATO, which in turn eased the path towards the creation of the China - NATO agreement on the joint anti-piracy operations in the Gulf of Aden (Cowie 2015)

Nonetheless, China has been engaging in some activities that have been criticised by the NATO member states. In 2017, Beijing conducted naval exercises with Russia in the Baltics. It has also increased its dealings with Ankara to promote developing formal ties with Turkey. The maintenance of a positive dialogue between the two was interrupted in 2016 due to the Chinese reforms in their armed forces and the terror attacks in Brussels in March 2016, which resulted in the postponement of the meetings between the Chinese and NATO officials (Duchatel 2018)

As for the NATO's approach to its security relationship with Asia, and, more specifically, with China, the organisation does not actively seek a role in Asia as such. At the same time, the security situation in the region of Asia Pacific as well as Central Asia cannot be regarded as completely detached from having a possible impact on the security and politics of the Euro - Atlantic region. As a result, to protect the interests and security of its member states, NATO is keen to understand the dynamics in Asia and remain involved in the region. In terms of the technical management of NATO's cooperation with China, the organisation's military interactions with the country, in the form of staff talks, follow a clear political direction that has been gradually clarifying over the past decade. These talks and meetings have proceeded in a regular manner, despite the recent obstacles. June $2^{\text {nd }}$, 2018 saw a high-level meeting between NATO's Deputy Secretary General Rose Gottemoeller and Deputy Chairman of the NATO Military Committee, Lieutenant General Steven Shepro who met with a Chinese delegation during the Shangri-La Dialogue in Singapore. Additionally, both NATO Secretary General Stoltenberg and Deputy Secretary General Gottemoeller met earlier this year with the Chinese Ambassador to the European Union. EacAll one of such high - level talks emphasise the need to strengthen the military dialogue between NATO and China. The topics in discussions usually related to the most contested areas, such as North Korea, South China Sea, Maritime Security and Counter Piracy efforts, as well as the security situation in Central Asia. One of the concrete outcomes of the staff talks is the "action 
list" of possible areas for cooperation to be developed together between NATO's and Chinese Military officials. Among the topics included on the list are exchanges such as: Chinese participation in courses at the NATO Defence College in Oberammergau, NATO participation in courses at China's Defence University, and a more effective information and intelligence exchange with regard to the communication between naval forces. The $6^{\text {th }}$ edition of the staff talks is already planned to take place in Beijing in 2019 (Duchatel 2018).

With Chinese defence capabilities on the rise, and Chinass renewed interest in securing strategic relations westwards, it is safe to suggest that the cooperation between NATO and Beijing will be developing in the near future, be it in terms of more regular talks or military and strategic collaboration or joint actions (Kissinger 2012, p. 210)

\section{China and Australia}

Due to Australia's relative geographical isolation from the regional club of liberal democracies, China has been the country's most significant economic partner. Recently, however, this relationship has come under significant strain. The growing Chinese diaspora has been increasingly active in its attempts to influence Australian political life. This was the case in late 2017, when the by - election campaign in New South Wales was dominated by an anonymous letter that strongly encouraged the Chinese community to vote against the "anti - Chinese" government in Canberra. The feeling of foreign interference it created resulted in an aggressive backlash against the growing Chinese diaspora. It was widely thought that the letter was issued by Beijing authorities wanting to influence Australian political life to its advantage by manipulating the Chinese citizens living in Australia. This has led to a backlash, especially from the right-wing parties (Brown 2018, p. 30). In addition, despite a traditionally introverted geopolitical stance, Australia has been growing in international importance in recent years, which has served as an ego boost and encouraged a more assertive posture.

With the election of president Trump, however, Australia has had to rethink its movement away from closer ties with China. Indeed, Canberra is finding the American foreign policy prioritisation of domestic national interests over the maintenance of strategic partnerships with its traditional allies worryingly unpredictable (Brown 2018, p.29). If 
China embraced liberal democratic values, it would be a clear alternative to the US for Canberra. However, such a scenario is unlikely to occur in the near future.

Canberra is also suspicious of Beijing's efforts to shape Australian society so that it becomes easier for it to integrate Chinese interests as their own. This is a matter of great concern for Australians, for whom national identity has always loomed large as a political issue. Indeed, with each changing government, ideas regarding whether Australia should integrate more within the Asian region or cultivate its ties with Europe and the US have been changing back and forth (Brown 2018, p. 28, Australian Centre on China in the world 2018). Consequently, right-wing Australian parties fear that if Australia continues to foster ties with both Washington and Beijing, it may become tangled between the two giants in the current disagreements (Australian Centre on China in the world 2018, Brown 2018, p.31)

China's direct approach to Australian domestic affairs does not help the situation. Recently, Beijing has vehemently demanded that Australian lecturers do not violate the official Chinese line on the South China Sea, Taiwan and Tibet. What is more, the Chinese embassy in Canberra has expressed its wish that local event organisers prohibit members of the Xinjiang minority from entering any Australian cultural events in the country. This creates criticism and anger amongst Australian who view China as meddling in their national affairs (Brown 2018, p. 30).

Regardless of these tensions, both Beijing and Canberra continue to make efforts to keep regular military and defence dialogue going (Wilh Wilhemsen Investments 2018). Currently, out of all of the 'Five-Eyes' intelligence-sharing community members, it is China that Australia has one of the closest defence links with. Bilateral exchanges are also continuously hosted between the Australian Defence Force (ADF) and the People's Liberation Army (PLA) (Wilh Wilhemsen Investments 2018, Australian Centre on China in the world 2018). The key leadership of the Australian Defence Force paid a visit to China last year and senior figures from the People's Liberation Army are also scheduled to be travelling to Australia. In October 2018, a Chinese navy ship was in Sydney as part of the International Fleet Review.

In terms of economic development, Australia is also unwilling to cut ties with China, nor would it be reasonable for Canberra to do so. The country has managed not to succumb fully to the 2008 crisis mainly thanks to its economic reliance on China's 
imports of Australian commodities. Even at present, trade with China constitutes a significant source of finance especially as Chinese exports from the US have dwindled.

Additionally, China, even though driven by national self- interest, does want Australia to function in line with the rule of law and remain a stable democracy. Beijing does not want to restructure the Australian ideological value system as long as Canberra does not attempt to export democratic ideas outside of its territorial borders. A system that proceeds in accordance with the liberal capitalistic premises usually makes for a reliable economic partner; therefore, it is easier to continue fostering positive relations with such. China does still grapple with its own security and related challenges such as its territorial disputes; it therefore needs as many regional allies as possible. The predictability of tAustralian politics stemming from the fact that Canberra is a liberal democracy makes it easier on China to predict its long - term objectives and assure protection of its economic initiatives with Canberra.

What may impede these ongoing efforts is cyber security (Wilhemsen Investments 2018). Australian governmental bodies and media have been complaining about cyber-attacks that were allegedly organised by the PLA. As a result, the Chinese telecommunications brand Huawei has been banned from being part of the Australian National Broadband Network (Australian Centre on China in the world 2018).

Additionally, challenges to the Beijing - Canberra security relationship will continue due to the traditional Australian focus on fostering close relations simultaneously with the US and China. Even though Beijing has been adamant about emphasising that it follows a policy of "peaceful rise", it is widely known that China perceives the American pivot as a calculated move to contain Chinese influence within the region. It is feared, especially by the right-wing Australian parties that as a result, Canberra may become tangled up between the two giants in the rising disagreement. Some observers agree that Beijing-Canberra defence exchange is essentially driven by pragmatism, it is characterised as a 'necessary supplement' to the broader economics (Brown 2018, p. 30).

\section{Concluding Insights}

Due to its political, economic and social development, and its rise to global power status, China's approach to its relations with foreign actors has undergone a profound 
change. Traditionally, a country that prioritised self-reliance, China is now emphasising initiatives that improve dialogue with external partners. Such a comprehensive shift away from traditional ways of perceiving relations with others is the product of a complex strategic thinking, pragmatism, and an awareness of the need to adapt to the necessities of the globalised world. It is also evidence that the Chinese are conscious of how to manage positive dialogue even with those whose ideological convictions run counter to those of the Party. As a result, Chinese success, be it in terms of its economic prosperity, social development or the continual improvement of its defence capabilities, reflects the leadership's strategic intelligence. This has been illustrated by the visible tendency amongst the actors studied in this paper, to look towards China for increased security dialogue and defence capabilities trade, instead of following the traditional westward direction for partnerships.

\section{Further Research}

This paper has only covered the most recent security developments between China and its Wests. Geostrategic thinking and national perspective on security are moulded by factors that have been influencing China's Western partners for decades if not centuries; therefore, a more thorough analysis is in order. Due to the extensiveness of the subject, however, these factors were only touched upon briefly in my paper.

As with all aspects of relations between actors, especially in terms of security, these also have an immense impact on the population. Thus, the potential harmful consequences of the evolving security dynamics between China and its partners on human development and well-being deserve an in-depth ongoing study to anticipate any potential harmful consequences in these areas.

Lastly, China has been investing increasing resources in initiatives promoting trade with Africa and Latin America. These expanding relations are of a more recent nature and deserve an extensive study, especially in terms of their long-term security implications as well as the potential consequences for the countries' defence industries resulting from defence trade with China. 


\section{Conclusion}

Due to its political, economic and social development, and its rise to the status of a global power, China's approach to its relations with foreign actors has undergone a profound change. Traditionally, a country that prioritised self-reliance and independence from foreign relations, China is now emphasising diverse initiatives that improve dialogue with external partners. Such in-depth ongoing change of a traditional way of perceiving relations with others is the product of complex strategic thinking, pragmatism, and an awareness of the need to adapt to the necessities of the modern, globalised world. This evolution of the traditional approach to security and defence is evidence that the Chinese are conscious of how to manage positive dialogue and keep diplomatic ties even with those whose ideological convictions run counter to those of the Party. As a result, China's success, be it in terms of its economic prosperity, social development, political power, or the continual improvement of its defence capabilities, reflects extensive practical knowledge of the leadership's strategic thinking on how to conduct modern diplomacy. This has been illustrated by the visible tendency amongst the actors, which have been studied in this paper, to look eastward - towards China for an increased security dialogue or defence capabilities trade, instead of following the traditional westward direction for partnerships.

\section{References}

American Historical Association, 2018. China and the West. [online]. Available from: https:// www.historians.org/about-aha-and-membership/aha-history-and-archives/gi-roundtableseries/pamphlets/em-42-our-chinese-ally-(1944)/china-and-the-west [Accessed 12 Aug 2018]. Australian Center on China in the World., 2018. The Australia - China Story. Defence and Strategic Relations. [online]. Available from: http://aus.thechinastory.org/archive/defenceand-strategic-relations/ [Accessed 31 Aug 2018].

Bolt, P. J., Cross, Sh. N., 2018. The China-Russia Security relationship. Asia Dialogue. [online]. Available from: http://theasiadialogue.com/2018/03/12/the-chinese-russian-securityrelationship/ [Accessed 30 July 2018].

Bray, D., Jeffrey, E. (eds.) New Mentalities of Government in China. Routledge: London.

Brown, K., 2018. "China’s Outback”. Planet China. Prospect Magazine, 28-31.

Chan, M., 2016. China battles Fierce Competition and quality issues in fight for weapons sales. South China Morning Post. [online]. Available from: https:/www.scmp.com/news/china/ 
diplomacy-defence/article/2039880/china-battles-fierce-competition-and-quality-issues [Accessed 12 Sept 2018].

Cowie, T., 2015. China and the West: Strengthening the Relationship. Global Public Policy Watch. [online]. Available from: https://globalpublicpolicywatch.org/2015/11/10/chinaand-the-west-strengthening-the-relationship/ [Accessed 3 Sept 2018].

De Haas, M., 2013. Russian - Chinese Security Relations. Moscow's threat from the East? Clingendael. Netherlands Institute of International Relations. [online]. Available from: https:// www.clingendael.org/sites/default/files/pdfs/20130327_rc_securityrelations.pdf [Accessed 20 July 2018].

Duchatel, M., 2018. China's military build-up may be a game changer for European arms transfers" South China Morning Post. [online]. Available from: https://www.scmp.com/news/ china/diplomacy-defence/article/2131937/chinas-military-build-may-be-game-changereuropean-arms [Accessed 25 July 2018].

Gady, F. S., 2016. Iran, China Sign Military Cooperation Agreement. The Diplomat. [online]. Available from: https://thediplomat.com/2016/11/iran-china-sign-military-cooperationagreement/ [Accessed 12 Sept 2018].

Gady, F. S., 2018. China's J-20 Fighter Undergoes First Over-the-Sea Combat Training. The Diplomat. Asia Defence. [online]. Available from: https://thediplomat.com/2018/05/chinasj-20-fighter-undergoes-first-over-the-sea-combat-training/ [Accessed 7 Sept 2018].

Gertz, B., 2016. Report: China’s Military Capabilities Are Growing at a Shocking Speed. The National Interest. [online]. Available from: https://nationalinterest.org/blog/the-buzz/reportchinas-military-capabilities-are-growing-shocking-18316 [Accessed 1 Sept 2018].

Gippner, O., 2016. Antipiracy and Unusual Coalitions in the Indian Ocean Region: China's Changing Role and Confidence Building with India. Journal of Current Chinese Affairs. Vol. 45(3), $107-137$.

Haenle, P., Gabuev, A., 2018. Putin's Fourth Term. Carnegie - Tsinghua Center for Global Policy. [online]. Available from: https://carnegietsinghua.org/2018/04/03/putin-s-fourth-termpub-75976 [Accessed 21 Apr 2018].

Hardy, J., Skomba, T., 2014. The global implications of China's military modernisation. HIS Markit. [online]. Available from: https://ihsmarkit.com/research-analysis/q12-the-globalimplications-of-chinas-military-modernization.html [Accessed 4 July 2018].

Hindy, L., 2017. A Rising China Eyes the Middle East. The Century Foundation. [online]. Available from: https://tcf.org/content/report/rising-china-eyes-middle-east/?agreed=1 [Accessed 12 Sept 2018].

Hua, Y., 2018. Novelty and Nostalgia. The Guardian.

Kissinger, H., 2012. On China. Penguin Books Ltd: London.

Legarda, H., 2017. China Global Security Tracker. China Monitor. [online]. Available from: https://www.merics.org/en/china-monitor/content/3211 [Accessed 12 Sept 2018].

Legarda, H., 2018. China as a Conflict Mediator: maintaining stability along the Belt and Road. IISS. [online]. Available from:https:/www.iiss.org/blogs/analysis/2018/08/china-conflictmediation-belt-and-road [Accessed 31 Aug 2018].

Luce, E., 2018. The West is doing its best to help China. Financial Times. Opinion Geopolitics. [online]. Available from: https://www.ft.com/content/66f99e1c-2143-11e8-9efc-0cd3 483b8b80 [Accessed 10 Aug 2018]. 
Maher, R., 2017. Europe's response to China's rise: competing strategic visions. Asial Europe (2017) 15, 133-145, [online]. Available from: https://doi.org/10.1007/s10308-017-04709 https://link.springer.com/article/10.1007/s10308-017-0470-9 [Accessed 25 July 2018].

Marcus, J., 2018. “'The globalisation' of China's military power.” BBC News. [online] Available: https://www.bbc.co.uk/news/world-asia-china-43036302 [Accessed 21 Aug 2018].

Nadimi, F., 2016, Iran and China Are Strengthening Their Military Ties. The Washington Institute, Improving the Quality of the U.S. Middle East Policy, [online]. Available from: https://www. washingtoninstitute.org/policy-analysis/view/iran-and-china-are-strengthening-their-mi litary-ties [Accessed 25 July 2018].

NATO, 2018. NATO and China resume military staff to staff talks. [online]. Available from: https://www.nato.int/cps/en/natohq/news_155840.htm [Accessed 26 July 2018].

Pacheco Pardo, R., 2017. Security relations between China and the European Union: from convergence to cooperation? European Security, 26(2), pp. 301-302.

Pantucci, R., Lain, S., 2017. China's Eurasian Pivot: The Silk Road Economic Belt. Whitehall Papers. RUSI. [online]. Available from: https://rusi.org/publication/whitehall-papers/ chinas-eurasian-pivot-silk-road-economic-belt [Accessed 25 July 2018].

Ratner, E., 2018. Rising to the China Challenge. Council on Foreign Relations. [online]. Available from: https://www.cfr.org/report/rising-china-challenge [Accessed 21 Aug 2018].

Rosecrance, R., 2006. Power and International Relations: The Rise of China and its Effects. International Studies Perspectives, 7(1), 31-35. [online] [Accessed 7 July 2018].

Shepherd, Ch., Michael, M., 2018. China boosts defence spending, rattling its neighbours' nerves. Reuters. [online]. Available from: https://uk.reuters.com/article/uk-chinaparliament-defence/china-boosts-defence-spending-rattling-its-neighbours-nervesidUKKCN1GG07D [Accessed 23 Aug 2018].

Wilh.Wilhemsen Investments, 2018. China and China to Strengthen Defence Ties. [online]. Available from: http:/www.wilh.com.au/wwi-industry-news-feed/china-and-australia-tostrengthen-defence-ties [Accessed 31 Aug 2018].

Wolf, M., 2018. How the West should judge a rising China. Advanced countries are hobbled by their inability to manager their own affairs" Financial Times. [online]. Available from: https:// www.ft.com/content/e30e9ed4-5754-11e8-bdb7-f6677d2e1ce8 [Accessed 2 Sept 2018].

Yao, J., 2014. First China-Iran joint military exercise attracts attention. China Military Online. Ministry of National Defence, The People's Republic of China. [online]. Available from: http:// eng.mod.gov.cn/DefenseNews/2014-09/23/content_4539380.htm [Accessed 12 Sept 2018].

Yu, P. H., 2018. China's Rise Will Continue, whether the West like it or not. South China Morning Post. Diplomacy. [online]. Available from: https://www.scmp.com/comment/insightopinion/article/2145155/chinas-rise-will-continue-whether-west-likes-it-or-not [Accessed 7 July 2018].

\section{Authors:}

Magdalena Markiewicz, MSc, Royal United Services Institute for Defence and Security Studies - RUSI (iD) https://orcid.org/0000-0001-7114-8932 